\title{
Effect of Planting Dates on the Performance of Promising Pigeonpea Genotypes under NEHZ
}

\author{
Lowrence Kithan ${ }^{*}$, Malini B. Sharma ${ }^{1}$ and Akumla Longchar ${ }^{2}$
}

*Scientist Agronomy, All India Coordinated Research Project (AICRP) on Pigeonpea, School of Agricultural Sciences and Rural Development (SASRD), Nagaland University, Medziphema Campus (797 106), India

${ }^{1}$ All India Coordinated Research Project (AICRP) on Pigeonpea, School of Agricultural Sciences and Rural Development (SASRD), Nagaland University, Medziphema Campus (797 106), India

${ }^{2}$ All India Coordinated Research Project (AICRP) on Pigeonpea, School of Agricultural Sciences and Rural Development (SASRD), Nagaland University, Medziphema Campus (797 106), India

\section{Corresponding Author}

Lowrence Kithan

e-mail: lowrencekithan@gmail.com

\author{
Article History \\ Article ID: IJEP0357 \\ Received in $05^{\text {th }}$ January, 2020 \\ Received in revised form $20^{\text {th }}$ January, 2020 \\ Accepted in final form $29^{\text {th }}$ January, 2020
}

\begin{abstract}
A field experiment was conducted during Kharif season of 2017 at All India Coordinated Research Project (AICRP) on pigeonpea experimental farm at School of Agricultural Sciences and Rural Development (SASRD), Nagaland University, Medziphema Campus. The objective of the study was to investigate the effect of different dates on performance of some improved pigeonpea varieties. The experiment comprised of three planting dates ( $1^{\text {st }}$ June, $15^{\text {th }}$ June and $1^{\text {st }}$ July) as factor $A$ and three pigeonpea varieties (UPAS 120, MANAK and PARAS) as factor B. The experiment was laid out in factorial randomized block design (FRBD) with three replications. Among growth parameters, maximum plant height $(163.2 \mathrm{~cm})$ and number of branches (15.8) were recorded with variety UPAS 120 at first date of sowing (1 $1^{\text {st }}$ June). Among yield parameters, maximum number of pods per plant (114.9) and maximum grain yield $\left(982.2 \mathrm{Kg} \mathrm{ha}^{-1}\right)$ were recorded at first date of sowing $\left(1^{\text {st }}\right.$ June) and with variety UPAS 120 (113.8 and $\left.968.8 \mathrm{Kg} \mathrm{ha}^{-1}\right)$.
\end{abstract}

Keywords: Planting date, pigeonpea, variety, yield

\section{Introduction}

Pigeonpea [Cajanus cajan (L.) Millsp.] is the second most important pulse crop of India after chickpea. In India, it is grown over an area of $0.38 \mathrm{~m}$ ha with a production of 0.33 $\mathrm{m} \mathrm{t}$ and the productivity is $859 \mathrm{~kg} \mathrm{ha}^{-1}$ (Anonymous, 2016a). The area and production of pigeonpea for the year 2015-2016 under Nagaland was 3050 ha and 2750 metric tonnes (Kharif) (Anonymous, 2017).

Pigeonpea have been cultivated for human and livestock consumption in many parts of the world as one of the most important leguminous and subsistence crop. Pigeonpea has the special morphological characters with respect to deep rooting and drought tolerance have made this crop adaptable in wide range of unfavourable growing conditions with uncertain rainfall and varied soil depth. It is often grown on marginal lands under rainfed conditions and usually intercropped with cereals and sole crop. The pigeonpea growers face several constraints which come in the way of boosting its productivity. The constraints include water stress (drought and water logging), non-availability of suitable varieties, existing varieties having different sowing windows, non-availability of inputs on time, adoption of inappropriate planting geometry and plant population and inadequate transfer of technology. The secret of boosting its yields mainly lies with suitable sowing date, varieties and spacing in pigeonpea.

Pigeonpea is perennial in nature, but with manipulation in the date of sowing, it could be made to look and behave like an annual herb and dry up at the end of its reproductive phase. Most varieties of pigeonpea are photoperiod-sensitive and, therefore, sowing date has an important influence on the vegetative and reproductive processes. Time of sowing, a non-monetary inputs, has a considerable influence on growth and yield of this crop. It ensures complete harmony between vegetative and reproductive phases on the one hand and climatic rhythm on the other. It also plays an important role in dry matter accumulation by the crop. Early sown crop may accumulate excessive dry matter and reduce podding, whereas late sown crop may reduce the biomass accumulation and consequently the reduction in yield. Delayed sowings beyond the optimum period result in low grain yields of pigeonpea (Rao et al., 2004; Kumar et al., 2008). 


\section{Materials and Methods}

An experiment was conducted at All India Coordinated Research Project (AICRP) on Pigeonpea experimental farm of School of Agricultural Sciences and Rural Development (SASRD) Medziphema, Nagaland under rainfed conditions to study the effect of different dates on performance of some improved pigeonpea genotypes under NEHZ. The experimental site is located at $25^{\circ} 45^{\prime} 43^{\prime \prime}$ North latitude and 93 $53^{\prime} 04^{\prime \prime}$ East longitude at an altitude of 310 meters above mean sea level. The prevailing climate represents sub-humid tropical climatic zone with high relative humidity, moderate temperature and medium to high rainfall. The mean temperature ranges from 21 oC to 30 ㅇ C during summer and rarely goes below $8^{\circ} \mathrm{C}$ in winter due to high atmospheric humidity. The average rainfall varies between 2,000 and 2,500 mm starting from April and ends with the month of September while the period from October to March remains completely dry. The soil of the experiment plot was categorized as sandy loam and well drained. The experiment was conducted in Factorial Randomized Block Design (FRBD) with two factors viz., different dates of sowing (D) and different genotypes (V). The different dates of sowing include D1- $1^{\text {st }}$ June, D2- $15^{\text {th }}$ June and D3- $1^{\text {st }}$ July, while the different genotypes include V1- UPAS 120, V2- MANAK and V3- PARAS, respectively. The experiment was conducted with three replications with nine treatments each.

\section{Results and Discussion}

\subsection{Phenophasic duration of pigeonpea}

The late sown crop took more time to attain $50 \%$ flowering but the active reproductive phase (pod initiation to maturity) was very much shortened. As a whole, the earlier sowing required more time to achieve harvest maturity, which progressively decreased with delay in sowing. Whereas with regard to variety an inquisition of the data revealed slightly significant variation among the different varieties.

\subsection{Number of pods plant ${ }^{-1}$}

The number of pods per plant at harvest was highest (114.9) in case of earlier sown crop of $1^{\text {st }}$ July. The late sown treatments (D2 and D3) recorded lower number of pods (94.9 and 86.8) per plant, respectively. On the other hand, the perusal of the data presented in Table 1 revealed that the maximum number of pods per plant (113.8) was reported in variety V1 i.e. UPAS 120 , which was statistically at par with varieties V2 and V3, respectively. Similarly, number of effective pods per plant was maximum in early sown crop (D1) which progressively decreased with delay in sowing. The vagaries in weather during late sowing might be the limiting factor for pod filling in case of late sown crop. Similar results have also been reported by Jayanna (2001).

\subsection{Number of seeds pod ${ }^{-1}$}

The number of seeds per pod, varied from 4.4 to 3.6, the highest being 4.4 at sowing date D2 and variety V1. However, the effect was statistically non significant. The lowest number

\begin{tabular}{|c|c|c|c|c|c|c|c|c|c|}
\hline Treatment & $\begin{array}{c}\text { Plant } \\
\text { height at } \\
\text { harvest } \\
(\mathrm{cm})\end{array}$ & $\begin{array}{l}\text { No. of } \\
\text { branch- } \\
\text { es plant }{ }^{-1}\end{array}$ & $\begin{array}{l}\text { Days to } \\
\text { first flow- } \\
\text { ering }\end{array}$ & $\begin{array}{l}\text { Days to } 50 \% \\
\text { flowering }\end{array}$ & $\begin{array}{l}\text { No. of } \\
\text { pods } \\
\text { plant }^{-1}\end{array}$ & $\begin{array}{l}\text { No. of } \\
\text { seeds } \\
\text { pod }^{-1}\end{array}$ & $\begin{array}{l}\text { Seed } \\
\text { weight } \\
\text { (g) }\end{array}$ & $\begin{array}{c}\text { Grain } \\
\text { yield (kg } \\
\mathrm{ha}^{-1} \text { ) }\end{array}$ & $\begin{array}{c}\text { Stalk yield } \\
\left(\mathrm{kg} \mathrm{ha}^{-1}\right)\end{array}$ \\
\hline \multicolumn{10}{|c|}{ Dates of sowing } \\
\hline D1(1st June) & 145.6 & 15.4 & 71.6 & 101.4 & 114.9 & 4.3 & 8.7 & 982.2 & 1913.5 \\
\hline D2(15th June) & 140.4 & 14.1 & 71.3 & 102.4 & 94.9 & 4.4 & 8.2 & 916.5 & 1612.3 \\
\hline D3(1st July) & 118.8 & 13.4 & 73.0 & 103.8 & 86.8 & 3.6 & 7.9 & 909.2 & 1655.4 \\
\hline SEm \pm & 1.77 & 0.14 & 0.15 & 0.16 & 1.93 & 0.02 & 0.03 & 4.89 & 18.38 \\
\hline CD (0.05\%) & 5.31 & 0.41 & 0.45 & 0.49 & 5.80 & 0.07 & 0.08 & 14.65 & 55.10 \\
\hline \multicolumn{10}{|l|}{ Varieties } \\
\hline V1 (UPAS 120) & 163.2 & 15.8 & 72.9 & 102.6 & 113.8 & 4.3 & 8.5 & 968.8 & 1768.5 \\
\hline V2 (Manak) & 119.2 & 14.8 & 72.0 & 102.2 & 95.0 & 4.0 & 8.0 & 932.9 & 1710.4 \\
\hline V3 (Paras) & 122.5 & 12.4 & 71.0 & 102.9 & 87.9 & 4.1 & 8.2 & 906.2 & 1702.3 \\
\hline SEm \pm & 1.77 & 0.14 & 0.15 & 0.16 & 1.93 & 0.02 & 0.03 & 4.89 & 18.38 \\
\hline CD $(0.05 \%)$ & 5.31 & 0.41 & 0.45 & 0.49 & 5.80 & 0.07 & 0.08 & 14.65 & NS \\
\hline \multicolumn{10}{|c|}{ Dates of sowing xvarieties } \\
\hline SEm \pm & 5.31 & 0.41 & 0.45 & 0.49 & 5.80 & 0.07 & 0.081 & 14.66 & 55.14 \\
\hline $\operatorname{CD}(p=0.05 \%)$ & NS & NS & NS & 1.47 & 17.39 & NS & NS & NS & NS \\
\hline CV (\%) & 11.81 & 8.51 & 1.89 & 1.43 & 17.60 & 5.25 & 2.94 & 4.70 & 9.58 \\
\hline
\end{tabular}


of seeds per pod (3.6) was noticed in sowing date D3. Laxminarayana (2003) also reported the similar results.

\subsection{Test weight (1000 grains weight in g)}

A close scrutiny of the data revealed that the test weight decreased with delay in sowing. The test weight was highest (8.7 g) in case of earlier sown crop i.e. D1 ( $1^{\text {st }}$ June). However, the difference among the late sown treatments was not significant. Singh and Srivastava (2002) also reported the similar results. On the other hand, among different varieties V1 i.e UPAS 120 showed the highest test weight ( $8.5 \mathrm{~g}$ ), however, it was found statistically non significant with other varieties.

\subsection{Grain yield ( $\left.\mathrm{kg} \mathrm{ha}^{-1}\right)$}

Seed yield of pigeon pea was highest $\left(982.2 \mathrm{~kg} \mathrm{ha}^{-1}\right)$ in case of earlier sown crop i.e. D1 ( $1^{\text {st }}$ June) which progressively decreased with delay in sowing from D2 to D3. The difference among D1, D2 and D3 was statistically found to be significant. There was decrease in grain yield when the crop was sown later after D3 ( $1^{\text {st }}$ July). Patel et al. (2000) also recorded the higher grain yield of cultivar GT-100 when sown earlier i.e. $30^{\text {th }}$ June. Rajput (1980) reported maximum seed yield when the crop sown on $10^{\text {th }}$ June as compared to $20^{\text {th }}, 30^{\text {th }}$ June and $20^{\text {th }}$ July. Similar results were also recorded by several workers (Kumar et al., 2008; Rani and Raji Reddy, 2010). Similarly, with regard to different genotypes, the highest grain yield (968.8 $\mathrm{kg} \mathrm{ha}^{-1}$ ) was recorded in V1 (UPAS 120) which was at par with sowing dates D2 and D3, respectively. Similar difference in grain yield of pigeonpea varieties was also reported by Prashanthi et al. (2001).

\section{Conclusion}

Basing on the above findings it can be concluded that sowing time plays a very crucial role when it comes to growth and yield performance of any crops and in this present context sowing of pigeonpea during the early first week of June is more productive as compared to late sowing with regard to growth and yield parameters. Also crop genotype plays an important and major role since it is directly or indirectly related to the climatic conditions and from these findings it can be concluded that variety UPAS 120 performed better on growth and yield as compared to MANAK and PARAS variety. Hence, this can be recommended for the farmers to take up but more research has to be carried out for more detailed studies of this findings.

\section{References}

Anonymous, 2016a. Agricultural Statistics at a glance. Visit at: www.agricoop. nic.in \& http:// eands.dacnet.nic.in

Anonymous, 2017. District wise Achievement of Area, Production and Yield for the year 2015-2016 in respect of Nagaland State. Directorate of Agriculture, Nagaland, Kohima, 1-7.

Jayanna, M., 2001. Effect of dates of sowing on growth and yield of short duration pigeon pea varieties during summer. Mysore Journal of Agricultural Sciences, 35, 313-315.

Kumar, N., Gopinath, K.A., Anil, K., Srivastva, Vinay Mahajan, 2008. Performance of pigeonpea (Cajanus cajan (L.) Millsp.) at different sowing dates in the mid-hills of Indian Himalaya. Archives of Agronomy and Soil Science 54, 507-514.

Laxminarayana, P., 2003. Response of rabi red gram to dates of sowing and row spacings. Annals of Agricultural Research 24, 187-189.

Patel, N.R., Mehta, A.N., Shekh, A.M., 2000. Radiation absorption, growth and yield of pigeonpea cultivars as influenced by sowing dates. Experimental Agriculture 36, 291-301.

Prashanthi, L., Vasanthi, R.P., Muneendra, BABU, 2001. Evaluation of pigeonpea genotypes for rainfed conditions in the Southern Zone of Andhra Pradesh, India. International Chickpea and Pigeonpea News Letter, 50-52.

Rajput, R.P., 1980. Response of soybean crop to climatic and soil environments. Ph.D. Thesis IARI, New Delhi, India.

Rani, B.P., Raji Reddy, D., 2010. Performance of pigeonpea in sole and intercropping system in vertisols of KrishnaGodavari zone in Andhra Pradesh. Indian Journal of Agricultural Research 44, 225-228.

Roa, P.R.S., Rao, K.N., Sridhara, S., Byregowda, M., Shankarlingappa, B.C., Meinke, H., DeVoil, P., Gadgil, S., 2004. Exploring cropping options with crop models- a case study of pigeonpea versus peanut in rainfed tracts of semi-arid southern India, Proceedings of the $4^{\text {th }}$ International Science Congress, September 26-October 1, 2004, Brisbane, Australia, 2004.

Singh, J.P., Srivastava, S.K., 2002. Effect of sowing time and row spacing on the performance of early maturing pigeon pea. Progressive Agriculture 2, 96-97. 